\title{
Field estimates of food consumption of the searobin Prionotus punctatus (Bloch, 1797) on the continental shelf off Ubatuba, southeastern Brazil
}

\author{
Lucy Satiko H. Soares'; A. Jarre-Teichmann² \& Carmen Lúcia Del Bianco Rossi-Wongtschowski \\ 'Instituto Oceanográfico da Universidade de São Paulo \\ (Caixa Postal 66149, 05315-970 São Paulo, SP, Brazil) \\ 2 Danish Institute for Fisheries Research, Department of Fish Biology \\ (Post-box 101, DK-9850 Hirtshals, Danmark)
}

- Abstract: Daily ration and population food consumption of juvenile and adult searobin Prionotus punctatus $(54-314 \mathrm{~mm}$ total length) were estimated for the southeastern Brazilian shelf off Ubatuba $\left(23^{\circ} 35^{\prime} \mathrm{S}, 45^{\circ} 00^{\prime} \mathrm{W}\right)$. Samples were collected during 24hour-fisheries in three periods during 1987/88. P. punctatus is a diurnal invertebrate feeder, its maximum stomach fullness occurred during the afternoon. Instantaneous gastric evacuation rates were estimated from the data, and daily ration was subsequently computed for total food intake, as well as the dominant prey items, comparing the results of three widely-used methods. The total daily ration for juveniles (total length < $150 \mathrm{~mm}$, average mass $15 \mathrm{~g}$ ) was estimated at $11.6 \%$ body wet mass in January 1987 (summer). The daily ration for adults ranged from $2.7-3.4 \%$ body wet mass in winterJuly 1988 (average body mass $80.6 \mathrm{~g}$ ), and from $3.1-4.1 \%$ body wet mass in summerDecember 1988 (average body mass $110.0 \mathrm{~g}$ ). The mean food consumption rate of the population was estimated at about 17 year $^{-1}$, corresponding to a gross efficiency of $7.3 \%$.

- Resumo: A ração diária e o consumo alimentar populacional foram estimados para jovens e adultos da cabrinha Prionotus punctatus (comprimento total: $54-314 \mathrm{~mm}$ ) da plataforma continental ao largo de Ubatuba, sudeste do Brasil. O estudo foi baseado em dados obtidos em três séries de amostras coletadas ao longo do ciclo de 24 horas, no inverno e verão do período de $1987 / 88$. P. punctatus é um comedor diurno, sendo que a repleção estomacal máxima ocorreu durante o período da tarde. As taxas de evacuação estomacal foram estimadas a partir dos dados de campo, as quais foram utilizadas para estimativas da ração diária. Esta foi estimada através de três métodos amplamente utilizados, obtendo-se resultados tanto para a ingestão total como para as principais presas. Jovens (comprimento total $<150 \mathrm{~mm}$; massa média do peixe $=15 \mathrm{~g}$ ) apresentaram ração diária de $11,6 \%$ da massa do corpo do peixe (\%MC) no verão-janeiro de 1987 . A ração diária dos adultos variou de 2,7-3,4\% MC no inverno-julho de 1988 (massa média do peixe $=80,6 \mathrm{~g}$ ), e de $3,1-4,1 \% \mathrm{MC}$ no verão-dezembro de 1988 (massa média do peixe $=110,0 \mathrm{~g}$ ). A estimativa da taxa de consumo populacional médio foi de $17 \mathrm{ano}^{-1}$, que corresponde à eficiência bruta de $7,3 \%$.

- Descriptors: Marine fish; Daily ration, Food consumption; Stomach content; Triglidae; Southeastern Brazil.

- Descritores: Peixe marinho, Ração diária, Consumo alimentar, Conteúdo estomacal, Triglidae, Sudeste do Brasil.

Contr. $n^{\circ} 81+$ do Inst. oceanogr. da Usp. 


\section{Introduction}

The searobin Prionotus punctatus is widely distributed on the inner southwestern Atlantic shelf between Central America and Argentina, on sandy and muddy bottoms. The species has low commercial value in the local fisheries (Figueiredo \& Menezes, 1980). It is a key species in the demersal fish community of the southeastern Brazilian shelf and occurs throughout the year, being more abundant off Ubatuba in periods with warmer water (autumn and winter) on the inner shelf (Rocha, 1990). $P$. punctatus feeds on slow moving benthic animals, mainly portunid crabs and penaeid shrimps (Soares \& Apelbaum, 1994). Although the prey items of this species are already known, no study has so far dealt with the estimation of its food consumption.

Field estimates of food consumption are important because they allow estimation of the energy input in the energy budget under natural conditions (e.g. Allen \& Wootton, 1984), and thus lead to a better understanding of the role of fish predators in the ecosystem. Further along this line, estimates of food consumption are needed as parameters in the trophic ecosystem models required for multispecies management (e.g. Gulland, 1983; Pauly, 1989).

The present study is part of the multidisciplinary project "Rational Utilisation of Coastal Ecosystems of the Brazilian Tropical Region, State of São Paulo", the main purpose of which was to obtain a thorough knowledge of the structure and basic features which account for the functioning of the ecosystem. It also has as a goal the modelling of the ecosystem on the basis a trophic model.

The objectives of this work are the estimation and comparison of the daily food intake of juvenile and adult $P$. punctatus under summer and winter conditions, as well as the derivation of the corresponding population's food consumption on the continental shelf off Ubatuba, Brazil.

\section{Material and methods}

\section{Study area}

The study site was located on the inner platform of the coastal system off Ubatuba $\left(23^{\circ} 35^{\prime} \mathrm{S}, 45^{\circ} 00^{\circ} \mathrm{W}\right)$ (Fig. 1). The bottom substratum consists mainly of sand and mud (Furtado \& Mahiques, 1990). Different water masses are present in this area during summer and winter. During summer, there is a high two-layer vertical stratification due to the seasonal thermocline: the upper layer consists of warmer and less saline Coastal Water $\left(\mathrm{T}=22-24^{\circ} \mathrm{C} ; \mathrm{S}=35-35.4\right)$, and the lower layer of colder South Atlantic Central
Water $\left(\mathrm{T}=14-15^{\circ} \mathrm{C} ; \mathrm{S}=35.6-35.8\right.$ ). During winter, only Coastal Water is present on the inner shelf (Castro Filho et al., 1987; Castro Filho, 1996). Thus there is a seasonal variation in the bottom water temperature, which could attain $10^{\circ} \mathrm{C}$ or even more.

The demersal ichthyofauna, sampled seasonally between 10 and $50 \mathrm{~m}$ depth during the period October 1985 to July 1987 by otter bottom trawl within the framework of the "Ubatuba integrated project", consisted of 111 species altogether. It varied seasonally with respect to species composition, abundance and species diversity (Rocha, 1990).

\section{Stomach content analysis}

For the estimation of the daily food intake, fish samples were collected from 24-hour-fisheries performed during 8-10 January 1987 (summer), 2224 July 1988 (winter) and 2-4 December 1988 (summer condition) in the coastal area off Ubatuba on board the R/V Prof. $W$. Besnard and the R/B Veliger II. Although the period 2-4 December is chronologically within the spring season, because summer and spring oceanographic conditions in the Ubatuba ecosystem present a similar dynamic (Castro Filho et al., op. cit.), it was considered as summer time.

The sampled fish were frozen $\left(-17^{\circ} \mathrm{C}\right)$ on board the vessel or stored on ice, and transferred to the laboratory. They were maintained in a freezer and thawed before being measured. Each specimen was measured to the nearest $\mathrm{mm}$ and weighed to the nearest $0.1 \mathrm{~g}$. The stomach was removed by cutting at the oesophageal sphincter and the pyloric caeca, and subsequently preserved in $10 \%$ formalin solution buffered with borax. Fish which had food items in their mouth or gill rakers, as well as fish with flaccid stomachs (indicating recent regurgitation) were discarded (Table 1). In the laboratory, the total stomach content was weighed to the nearest $0.01 \mathrm{~g}$ and expressed as a percentage of body wet mass $(\% \mathrm{BM})$. The major food items were sorted out and weighed to the nearest $0.001 \mathrm{~g}$.

The percent body mass (\%BM) was calculated by the equation: $\% \mathrm{BM}=$ stomach content mass $(\mathrm{g}) /$ fish body mass * 100 .

After joining the samples into one single 24hour-cycle per sampling period, the midpoint of each hauling period was used as a reference point in time. Sampling times which were less than half an hour apart were brought together into one single sample, and the midpoints averaged. The frequency distributions of the relative stomach contents (\%BM) were subsequently analysed for each sampling point in time to decide on an appropriate measure for the central tendency of the sample. 


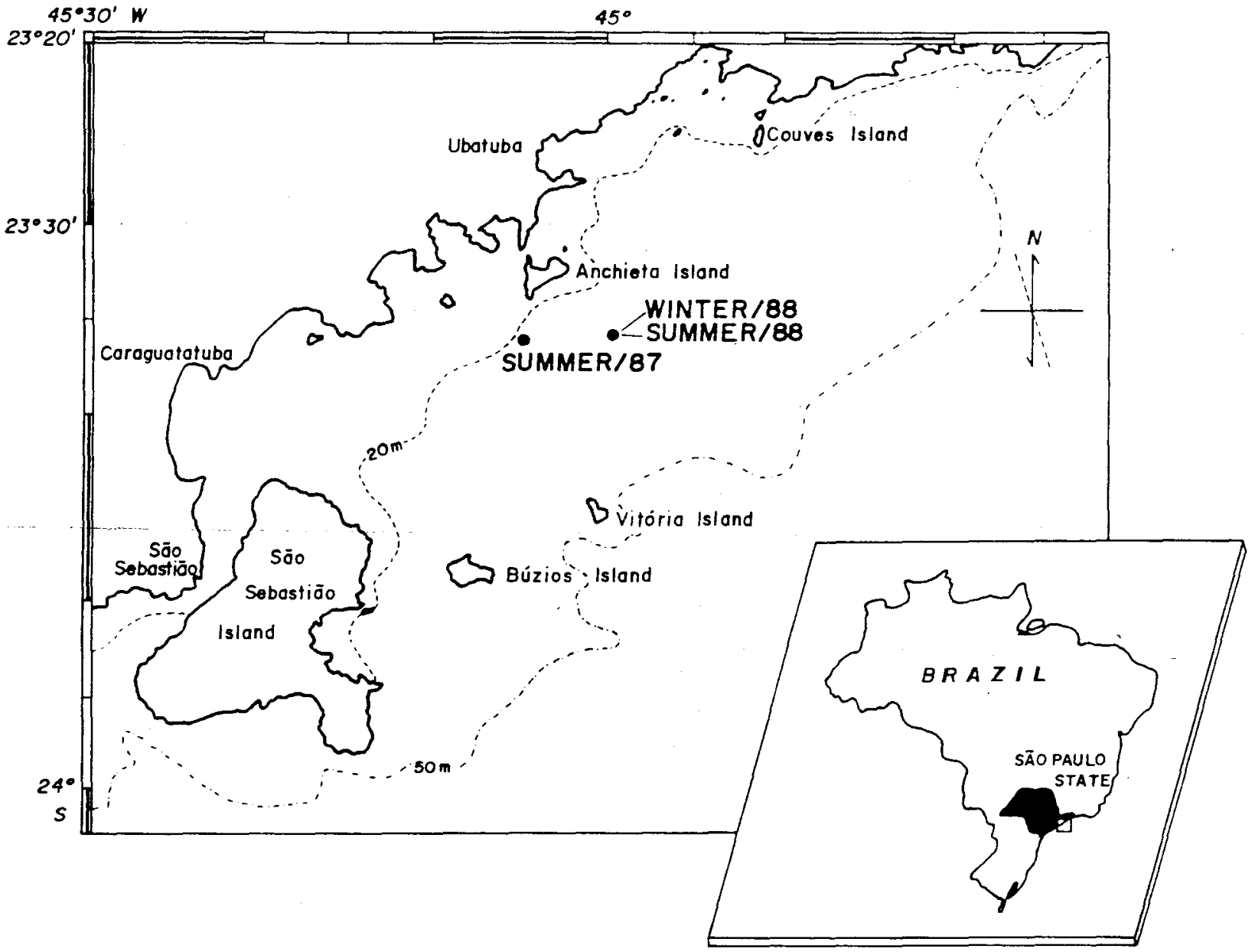

Fig. I. The sampling locations on the southeastern Brazilian shelf off Ubatuba.

In order to estimate the daily ration. the evacuation rate was computed from the descending branch of the stomach content trajectory, taking the exponential model of gastric evacuation into consideration, which was suggested as probably being the most appropriate for describing evacuation in most fish species (Héroux \& Magnan, 1996). This model is expressed as:

$$
\mathrm{S}_{1}=\mathrm{S}_{0} \mathrm{e}^{-\mathrm{Et}}
$$

where $S_{0}$ is the amount of food at the beginning of the time interval, $S_{t}$ is the amount of food at time $t$ and $\mathrm{E}$ the evacuation rate (in hour ${ }^{-1}$ units).

The daily rations were subsequently computed comparing three widely-used methods. As the first, the "modified Bajkov" exponential model was used (Bajkov, 1935; Eggers, 1979), where the daily food intake of a fish is estimated as the product of the evacuation rate and the average stomach content over 24 hours,

$$
R_{d}=\operatorname{avg} .\left(S_{t}\right) \cdot E \cdot 24 \text { hours }
$$

Secondly, the exponential model described by Elliott \& Persson (1978) was used, where the consumption during each sampling interval $t$ is computed from an estimate of the evacuation rate $\mathrm{E}$ and the observed stomach contents $S_{o}$ and $S_{t}$ at the beginning and end of that interval, thus

$$
C_{t}=\left(S_{t}-S_{0} e^{-E \cdot t}\right) \cdot E \cdot t /\left(1-e^{-E \cdot t}\right)
$$

The daily ration is then computed as the sum of the amounts consumed over a 24 -hour period, i.e.,

$$
\mathrm{R}_{\mathrm{d}}=\Sigma_{\mathrm{i}} \mathrm{C}_{\mathrm{i}}
$$

This model has been broadly used for food consumption studies and has proved particularly useful in determining the daily food intake of fish from field samples (Allen \& Wootton, 1984; Livingston et al., 1986). 
Table 1. Summary of the samples of $P^{\prime}$. punclums obtained per 30 min trawling. T-mean bottom water tenperature.

\begin{tabular}{|c|c|c|c|c|c|c|c|c|}
\hline Date & $\begin{array}{c}\text { Time } \\
\text { (hour) }\end{array}$ & $\begin{array}{c}\text { Total } \\
\text { samples } \\
\text { (nimber) }\end{array}$ & $\begin{array}{c}\text { Juvenile } \\
\text { samples } \\
\text { (number) }^{2}\end{array}$ & $\begin{array}{c}\text { Adult } \\
\text { samples } \\
\text { (number) }^{2}\end{array}$ & $\begin{array}{c}\text { Mean } \\
\text { total length } \\
(\mathrm{mm})\end{array}$ & S.e. ${ }^{3}$ & $\begin{array}{c}\text { Mean body } \\
\text { mass (g) }\end{array}$ & S.e. ${ }^{3}$ \\
\hline Summer 1987 & 02.16 & $21(00)$ & $15(03)$ & $06(01)$ & 123.6 & 6.3 & 27.2 & 3.4 \\
\hline \multirow[t]{3}{*}{ 08-10 January } & 05.47 & $24(00)$ & $23(00)$ & $01(00)$ & 100.6 & 2.9 & 13.4 & 1.3 \\
\hline & 08.23 & $22(00)$ & $19(00)$ & $03(00)$ & 94.0 & 4.4 & 11.8 & 1.6 \\
\hline & 11.36 & $28(00)$ & $26(00)$ & $02(00)$ & 99.8 & 4.4 & 15.5 & 2.2 \\
\hline \multirow[t]{4}{*}{$\mathrm{T}=16.8^{\circ} \mathrm{C}$} & 14.22 & $17(00)$ & $16(00)$ & $01(00)$ & 104.3 & 4.0 & 14.5 & 1.4 \\
\hline & 17.08 & $17(00)$ & $15(01)$ & $02(00)$ & 103.2 & 5.9 & 16.4 & 2.7 \\
\hline & 20.18 & $25(00)$ & $24(00)$ & $01(00)$ & 91.2 & 5.0 & 13.0 & 2.1 \\
\hline & 23.05 & $18(00)$ & $16(01)$ & $02(00)$ & 89.8 & 5.1 & 10.6 & 1.7 \\
\hline Grand mean/Total & & $172(00)$ & $154(05)$ & $18(01)$ & 100.0 & 1.8 & 15.0 & 0.8 \\
\hline Winter 1988 & 00.25 & $22(03)$ & $04(01)$ & $15(05)$ & 180.5 & 6.8 & 81.9 & 10.9 \\
\hline \multirow[t]{5}{*}{ 22-24 July } & 03.17 & $25(05)$ & $04(02)$ & $16(08)$ & 182.6 & 6.0 & 83.2 & 10.1 \\
\hline & 04.05 & $09(03)$ & $01(00)$ & $05(05)$ & 176.8 & 9.1 & 75.0 & 12.7 \\
\hline & 06.31 & $14(00)$ & $02(02)$ & $12(04)$ & 176.2 & 5.7 & 73.8 & 8.0 \\
\hline & 09.28 & $28(01)$ & $(04(00)$ & $23(00)$ & 183.9 & 5.5 & 82.8 & 9.7 \\
\hline & 11.01 & $14(01)$ & $04(00)$ & $09(00)$ & 185.7 & 6.9 & 85.1 & 10.7 \\
\hline \multirow[t]{5}{*}{$\mathrm{T}=19.7^{\circ} \mathrm{C}$} & 12.35 & $11(02)$ & $00(00)$ & $09(00)$ & 177.3 & 6.3 & 71.7 & 7.9 \\
\hline & 15.33 & $29(03)$ & $04(00)$ & $22(00)$ & 179.2 & 6.1 & 78.9 & 10.2 \\
\hline & 18.44 & $46(04)$ & $11(00)$ & $31(01)$ & 181.5 & 5.1 & 83.2 & 9.6 \\
\hline & 21.26 & $21(02)$ & $03(00)$ & $16(03)$ & 181.9 & 7.8 & 86.1 & 14.6 \\
\hline & 22.00 & $28(09)$ & $03(01)$ & $16(01)$ & 175.4 & 6.3 & 74.8 & 8.7 \\
\hline Grand mean/Total & & $247(33)$ & $40(06)$ & $174(27)$ & 180.5 & 1.9 & 80.6 & 3.3 \\
\hline Summer 1988 & 02.15 & $06(00)$ & $01(00)$ & $05(0 \mathrm{I})$ & 194.8 & 8.9 & 103.7 & 17.7 \\
\hline \multirow[t]{4}{*}{ 02-04 December } & 03.35 & $04(00)$ & $01(00)$ & $03(00)$ & 204.7 & 8.6 & 112.0 & 14.8 \\
\hline & 05.18 & $13(01)$ & $03(00)$ & $09(01)$ & 189.1 & 5.0 & 86.8 & 6.5 \\
\hline & 08.20 & $07(02)$ & $02(00)$ & $03(00)$ & 199.3 & 7.8 & 106.1 & 13.1 \\
\hline & 11.17 & $09(00)$ & $(11(00)$ & $08(01)$ & 178.0 & 6.7 & 72.4 & 8.2 \\
\hline \multirow[t]{5}{*}{$\mathrm{T}=15.8^{\circ} \mathrm{C}$} & 14.23 & $12(03)$ & $00(00)$ & $09(00)$ & 220.0 & 15.7 & 167.9 & 39.5 \\
\hline & 17.26 & $11(02)$ & $(12(00)$ & $07(00)$ & 187.7 & 8.6 & 90.9 & 12.4 \\
\hline & 20.15 & $23(03)$ & $04(00)$ & $16(01)$ & 187.6 & 5.4 & 90.2 & 8.0 \\
\hline & 21.36 & $17(00)$ & $05(00)$ & $12(00)$ & 191.6 & 8.0 & 103.1 & 14.6 \\
\hline & 23.15 & $18(05)$ & $02(00)$ & $11(00)$ & 222.7 & 10.9 & 160.8 & 28.6 \\
\hline Grand mear $/$ otal & & $120(16)$ & $21(00)$ & $83(04)$ & 197.1 & 3.3 & 110.0 & 7.2 \\
\hline
\end{tabular}

Thirdly, an iterative method, the "integrated approach" MAXIMS software (Jarre-Teichmann et al., 1992) was used. This employs a non-linear leastsquares algorithm to fit a consistent time trajectory to a 24-hour-cycle of stomach contents for species showing either one or two feeding periods per day. The daily ration is subsequently computed as the integral of the stomach content's trajectory over the feeding phase.

For comparative purposes, the stomach evacuation rate was estimated on basis of regressions developed by Durbin et al. (1983) and Worobec (1984). These authors found a general relationship between the evacuation rate and the temperature for several species of fish feeding on small invertebrate prey, as is the case for $P$. punctatus (Soares \& Apelbaum, 1994). The regression equations read

$$
\begin{aligned}
& \mathrm{R}=0.0406 \mathrm{e}^{0.111 \mathrm{~T}} \text { (Durbin et al., 1983). } \\
& \mathrm{R}=-0.0442+0.0175 \mathrm{~T} ; \text { (Worobec, 1984) }
\end{aligned}
$$

where $T$ is the average bottom temperature estimated over a $24 \mathrm{~h}$ cycle.

The rate of population food consumption $\mathrm{Q} / \mathrm{B}$ (in time ${ }^{-1}$ units) was estimated using MAXIMS software (Jarre-Teichmann et al., 1992), based on 
growth and mortality parameters estimated by Peria (1995). Daily food intake estimates were selected based on a hierarchy of estimates obtained by the integrated approach, the point-to-point method, and the modified Bajkov model, in accordance with the criteria proposed by Jarre-Teichmann (1992).

This rate is given by

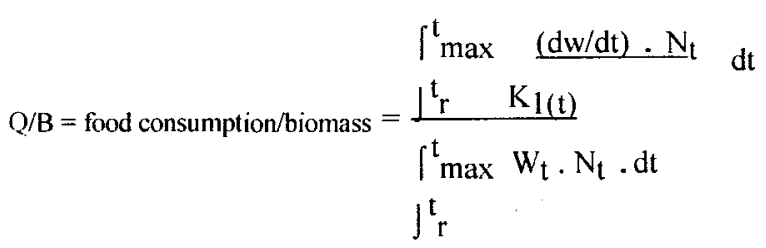

where $t_{r}$ is the age at entry, and $t_{\max }$ the age of exit from the population, $N_{t}$ the population size, $K_{l(t)}$ the gross food conversion efficiency at age $t$, and $W_{t}$ is the weight at age $t$ (Pauly, 1986).

We also estimated the daily ration for $P$. punctatus on the basis of the shape of its caudal fin (aspect ratio, A), the environmental temperature $T\left({ }^{\circ} \mathrm{C}\right)$, the asymptotic mass $W_{\infty}$, and the food type $F$ (defined as 0 for carnivores/omnivores and 1 for herbivores/detritivores) (Palomares \& Pauly, 1989). Their equation reads

$\ln R d=-0.1775-0.2018 \ln W_{\infty}+0.6121 \ln T+0.5156 \ln \mathrm{A}+1.26 \mathrm{~F}$

$\left(r^{2}=0.865\right.$, d.f. $\left.=28\right)$

The aspect ratio of caudal fin is an index of the activity level of the fish and is calculated by the ratio $\mathrm{h} 2 / \mathrm{s}$ ( $\mathrm{s}=$ surface area; $\mathrm{h}=$ height). In this study this value was estimated from a drawing in an identification key (Figueiredo \& Menezes, 1980) at 1.63. The $W_{\infty}$ value estimated by Peria (1995) at $906.6 \mathrm{~g}$ was used.

In order to establish the relationship between the daily food intake and the condition of the lish, the allometric condition factor K (Ricker, 1975) was calculated for each specimen from the expression:

$$
\mathrm{K}=\mathrm{W}_{\mathrm{t}} / \mathrm{L}_{\mathrm{t}}^{\mathrm{b}}
$$

where $W_{t}$ is the wet mass of the fish and $L_{t}$ its total length. The exponent $b(=3.114)$ estimated for the population of $P$. punctatus on the continental shelf off Ubatuba (Peria, op. cit.) was used. The values were compared by using a Kruskal-Wallis test (Zar, 1996).

\section{Results}

The sample of summer 1987 was composed mainly of juveniles of less than $150 \mathrm{~mm}$ total length $(90 \%)$, whereas the samples of winter and summer 1988 consisted mainly of adults $(81 \%$ and $80 \%$, respectively). Therefore, the daily food intake was studied for juveniles in summer 1987 and for adults in summer and winter 1988 (Table 1). A variable proportion of them had empty stomachs during the three periods.

The geometric mean of the relative stomach contents was selected, after distribution analysis, as an appropriate measure of the central tendency for all samples. The trajectories of observed stomach contents are given in Figures 2-4 for the three sampling dates. Both juvenile and adult searobin showed a marked diel pattern in feeding activity in summer as well as in winter. Feeding occurred during daylight hours, i.e., feeding activity increased after sunrise (5-6 $\mathrm{h}$ in summer; 6-7 $\mathrm{h}$ in winter) and declined around sunset (18-19 h in summer; $17-18 \mathrm{~h}$ in winter). The stomachs were almost empty a few hours after midnight.

Differences in the trajectories depending on the prey item were observed. Juveniles ingested megalops mainly in the morning, but fed on shrimps and crabs throughout the day (Fig. 2). Adults generally showed a clear diel pattern for shrimps, but not for crabs (Figs 3-4).

The evacuation rates estimated by the different methods for the seasonal samples are given in Table 2. They could be estimated for the total stomach content and for the most important food items, except for adults feeding on crabs in winter 1988. As may be seen from the coefficients of determination, these estimates are significant for total stomach content and for shrimps for juveniles and for adults. By using the integrated approach, estimates were obtained of the total daily ration of adults in summer and winter, and for their daily intake of shrimps in winter. In these three cases, the evacuation rates were lower than those determined from the examination of the evacuation phase alone. The estimates calculated from the regressions proposed by Durbin et al. (1983) and by Worobec (1984) were quite different from those obtained from the data of this present study.

Figure 5 gives the time trajectories fitted to the stomach contents data of adult $P$. punctatus by using the integrated approach. It is immediately evident from the trajectories that the simple exponential evacuation model adequately fitted the data for total stomach contents as well as for shrimps. As expected, the feeding interval was longer during summer ( 14 hours) than during winter (10 hours), but the feeding and evacuation rates were different, yielding similar estimates of daily rations as between seasons. 

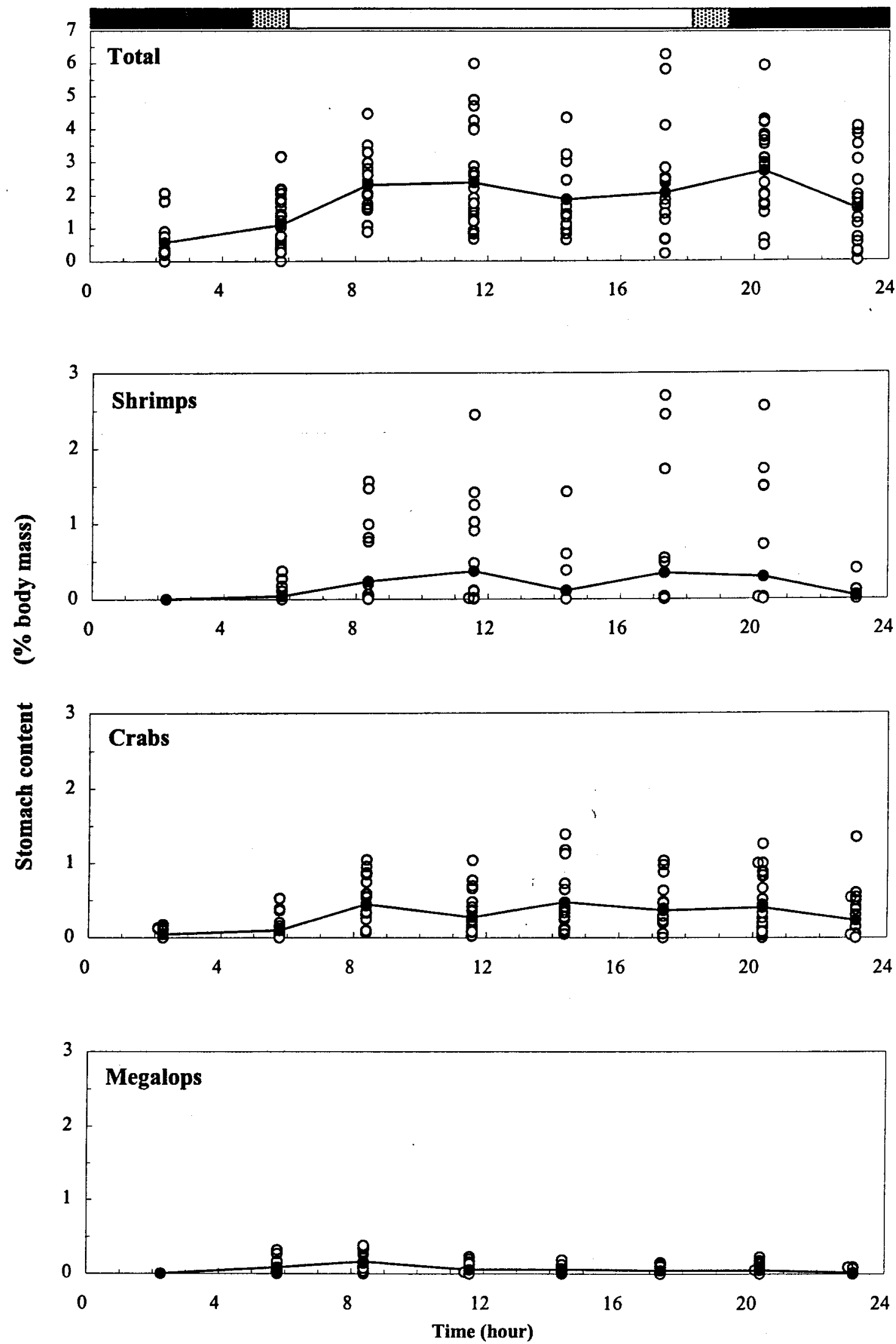

Fig. 2. Time trajectory of stomach contents of juvenile $P$. punctatus sampled during 8-10 January 1987. Open circles represent actual observations, filled circles the geometric mean of each sample. White bar represents daytime, black bar night time and dotted bar dawn and dusk. 

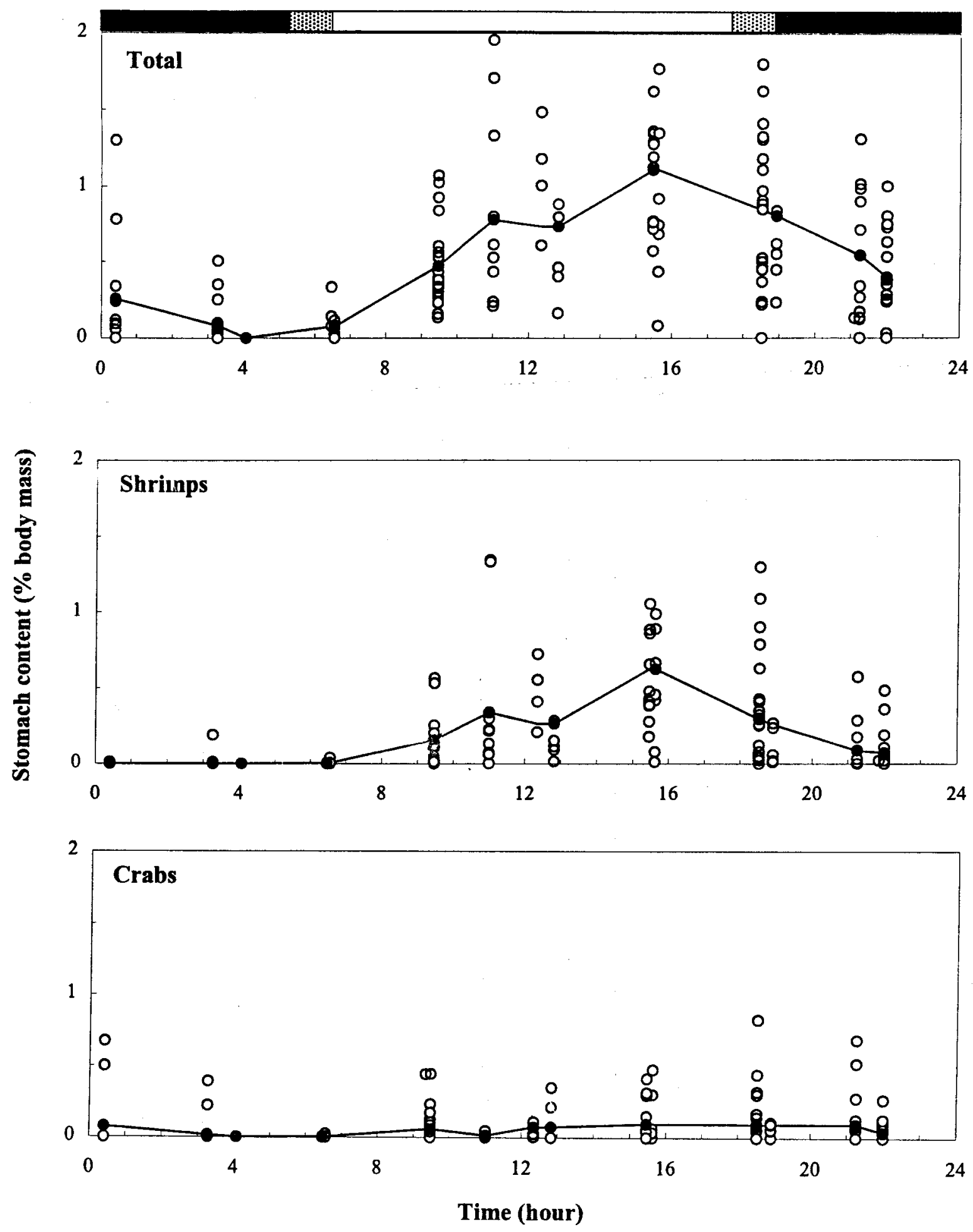

Fig. 3. Time trajectory of stomach contents of adult $P$. punctatus sampled during 22-24 July 1988. Open circles represent actual observations. filled circles the geometric mean of each sample. White bar represents daytime, black bar night time and dotted bar dawn and dusk. 

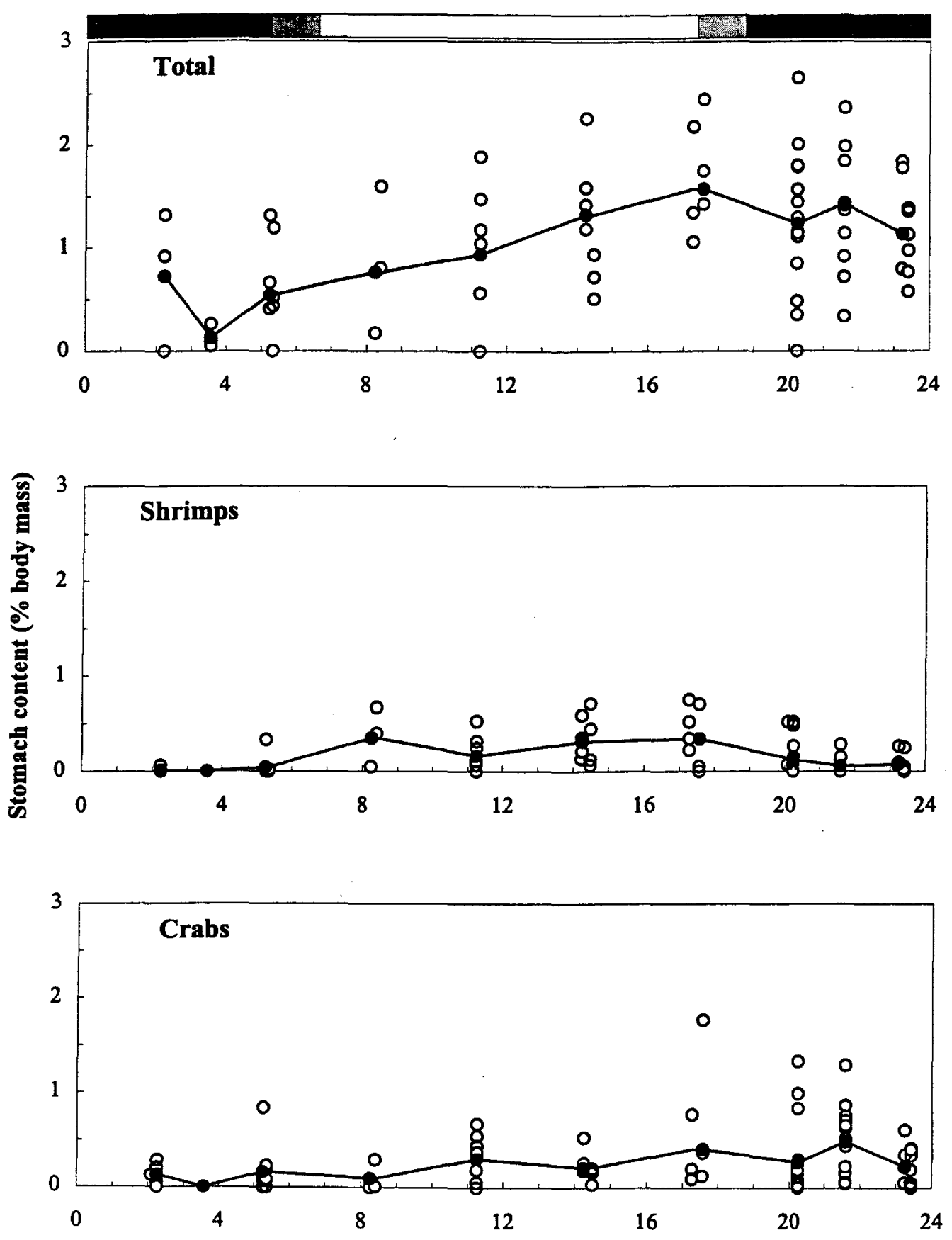

Fig. 4. Time trajectory of stomach contents of adult $P$. punctatus sampled during 2-4 December 1988. Open circles represent actual observations. filled circles the geometric mean of each sample. White bar represents daytime, black bar night time and dotted bar dawn and dusk. 
Table 2. Estimates of evacuation rate of juvenile and adult $P$. punctatus during different seasons of 1987 and 1988, obtained from four different approaches.

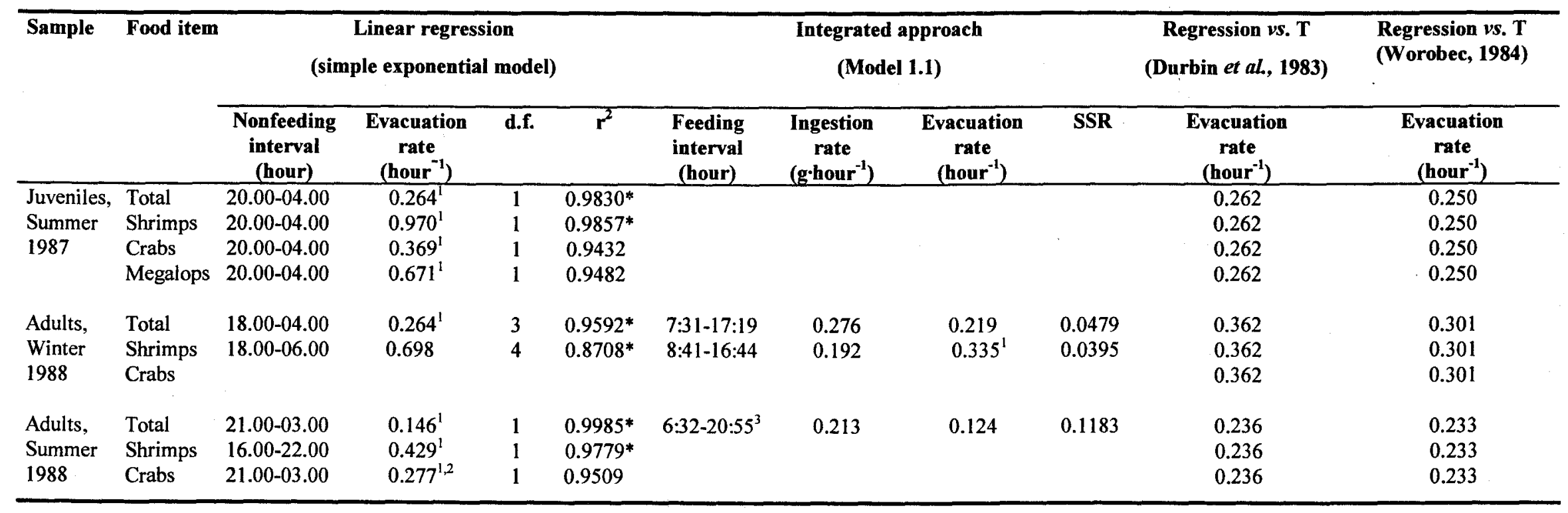

Significant, $\mathrm{P}<0.05$

Value used in estimation of daily ration following the "modified Bajkov" and the "Elliott and Persson" models.

Value used for estimation of daily ration of crabs of adult $P$. punctatus in winter 1988.

Value of sampling time 03.35 omitted due to low sample size and apparent lack of fit to the overall trajectory 

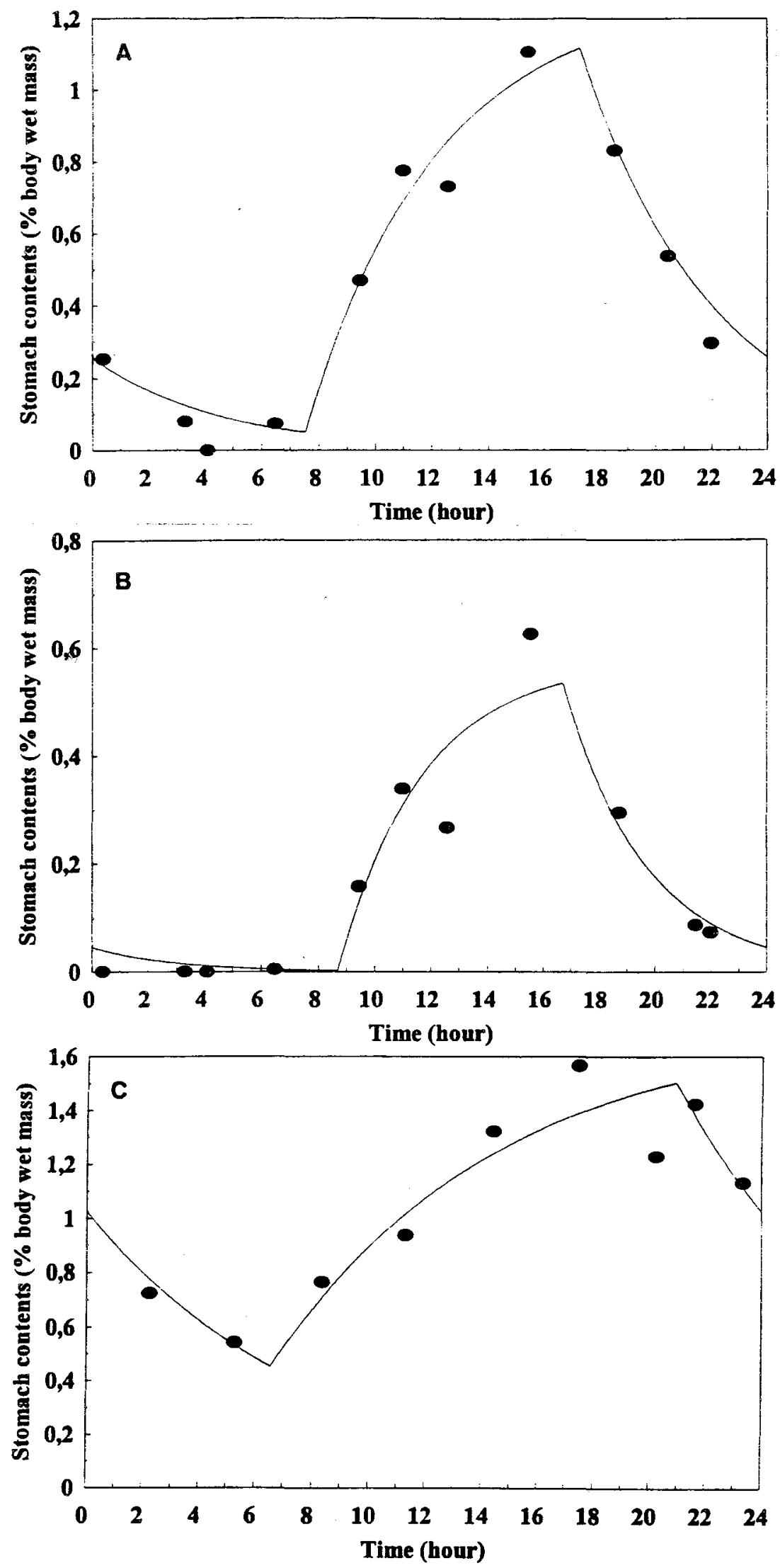

Fig. 5. Diel trajectory of stomach contents of $P$. punctatus as estimated by the integrated approach of Jarre et al. (1991). (A) Adults, winter 1988, total stomach contents; (B) Adults, winter 1988, shrimp content; (C) Adults, summer 1988, total stomach contents. 
Table 3 shows the estimated size-specific daily rations. Searobin juveniles showed the highest daily intake values of about $11.6 \%$ of body mass. Adults showed approximately similar values as between summer and winter, with estimates of total daily intake of between 2.7 and $4.1 \%$ of body mass. For juveniles, the estimates obtained using the two methods were closely similar both for total stomach content and for each prey item. For adults, the integrated approach gave the lowest estimates for total stomach content both in summer and winter; and for shrimps in the winter.

Table 4 gives our estimates of annual population food consumption of $P$. punctatus based on the above estimates of daily ration, as well as its population growth and mortality parameters. The food consumption of the total population was 17 year ${ }^{-1}$, or $4.6 \%$ day $^{-1}$, yielding a gross efficiency (ratio of production to consumption) of $7.3 \%$. As expected, the population's estimated consumption was much higher for juveniles $\left(\mathrm{Q} / \mathrm{B}=9.9 \% \mathrm{day}^{-1}\right)$ than for adults $\left(\mathrm{Q} / \mathrm{B}=2.8 \%\right.$ day $\left.^{-1}\right)$. The maintenance ration of the population of $P$. punctatus was estimated at 10.4 year $^{-1}$, or about $60 \%$ of the total consumption.

Table 3. Estimates of daily ration (\% body wet mass day ${ }^{-1}$ ) obtained for juvenile and adult $P$. punctatus during different seasons of 1987 and 1988. See text for details on the methods used.

\begin{tabular}{|c|c|c|c|c|c|c|c|}
\hline Sample & $\mathbf{T}^{\circ} \mathbf{C}$ & $\begin{array}{l}\text { Food } \\
\text { item }\end{array}$ & $\begin{array}{c}\text { Modified } \\
\text { Bajkov (1935) }\end{array}$ & $\begin{array}{c}\text { Dillint \& Persson } \\
(1978)\end{array}$ & $\begin{array}{l}\text { Jarre et al. } \\
\text { (1991) }\end{array}$ & $\begin{array}{c}\text { Value used in } \\
\text { computation } \\
\text { of } Q / B\end{array}$ & $\begin{array}{c}\text { Palomares \& Pauly } \\
(1989)^{*}\end{array}$ \\
\hline $\begin{array}{l}\text { Juveniles, } \\
\text { Summer } \\
1987\end{array}$ & 16.8 & $\begin{array}{l}\text { Total } \\
\text { Shrimps } \\
\text { Crabs } \\
\text { Megalops }\end{array}$ & $\begin{array}{r}11.55 \\
4.12 \\
2.57 \\
0.95\end{array}$ & $\begin{array}{l}11.55 \\
4.07 \\
2.55 \\
0.93\end{array}$ & . & $\begin{array}{r}11.6 \\
4.1 \\
2.6 \\
0.9\end{array}$ & $\begin{array}{l}1.53 \\
\text { n.a. } \\
\text { n.a. } \\
\text { n.a. }\end{array}$ \\
\hline $\begin{array}{l}\text { Adults, } \\
\text { Winter } \\
1988\end{array}$ & 19.7 & $\begin{array}{l}\text { Total } \\
\text { Shrimps } \\
\text { Crabs }\end{array}$ & $\begin{array}{l}3.03 \\
2.82 \\
0.34\end{array}$ & $\begin{array}{l}3.44 \\
1.62 \\
0.48\end{array}$ & $\begin{array}{l}2.71 \\
1.55\end{array}$ & $\begin{array}{l}2.7 \\
1.6 \\
0.5\end{array}$ & $\begin{array}{l}1.69 \\
\text { n.a. } \\
\text { n.a. }\end{array}$ \\
\hline $\begin{array}{l}\text { Adults, } \\
\text { Summer } \\
1988\end{array}$ & 15.8 & $\begin{array}{l}\text { Total } \\
\text { Shrimps } \\
\text { Crabs }\end{array}$ & $\begin{array}{l}3.43 \\
1.51 \\
1.52\end{array}$ & $\begin{array}{l}4.07 \\
1.81 \\
1.73\end{array}$ & 3.06 & $\begin{array}{l}3.1 \\
1.8 \\
1.7\end{array}$ & $\begin{array}{l}1.48 \\
\text { n.a. } \\
\text { n.a. }\end{array}$ \\
\hline
\end{tabular}

"This regression estimates food consumption of the total population, and not a size-specific daily ration as the other methods.

The results should hence be compared to those of Table 4, but are listed here for practical reasons.

Table 4. Estimation of population fixd consumption obtained for $P$. punctatus on the shelf off Ubatuba, southeastem Brazil, based on size-specific daily rations from stomach contents sampled at sea; and for Eutrigla gurnardus from North Sea (De Gee \& Kikkert. 1993).

\begin{tabular}{|c|c|c|c|c|}
\hline \multirow[t]{2}{*}{ Parameters } & \multicolumn{3}{|c|}{ Priomotus punctatus } & \multirow{2}{*}{$\frac{\text { Eutrigla gurnardus }}{\text { Total population }}$} \\
\hline & Juveniles & Adults & $\begin{array}{c}\text { Total } \\
\text { population }\end{array}$ & \\
\hline$W_{\infty}(g)$ & 906.6 & 906.6 & 906.6 & 782.6 \\
\hline $\mathrm{K}\left(\right.$ year $\left.^{-1}\right)$ & 0.285 & 0.285 & 0.285 & 0.079 \\
\hline b & 3.114 & 3.114 & 3.114 & 3.10 \\
\hline B & 0.0265 & 0.0265 & 0.0265 & 0.0127 \\
\hline$Z\left(\right.$ year $\left.^{-I}\right)$ & 1.2440 & 1.2440 & 1.2440 & 1.2440 \\
\hline$W_{r}(g)$ & 2.40 & 43.3 & 2.40 & 2.60 \\
\hline$W_{\max }(g)$ & 45.2 & 422.0 & 422.0 & 668.3 \\
\hline $\mathrm{Q} / \mathrm{B}\left(\right.$ year $\left.^{-1}\right)$ & 36.1 & 10.1 & 17.0 & 13.9 \\
\hline $\mathrm{Q} / \mathrm{B}\left(\% \mathrm{day}^{-1}\right)$ & 9.9 & 2.8 & 4.6 & 3.8 \\
\hline G.E. $(\%)$ & 3.5 & 12.3 & 7.3 & 9.0 \\
\hline
\end{tabular}


The Kruskall-Wallis analysis showed the heterogeneity of the condition factors of the total samples collected in the summer 1987 and in winter and summer $1988\left(\chi^{2}=80.20 ; p<0.001\right)$. The highest value (7.64) was observed in summer 1987, when the sample was mainly composed of juveniles. The condition factors of winter and summer 1988 (6.97 and 7.03, respectively), when the sample was composed mainly of adults, were very similar. Figure 6 shows the distribution of individual condition factors in relation to size, and the proportion of adults in final gonadal maturation.
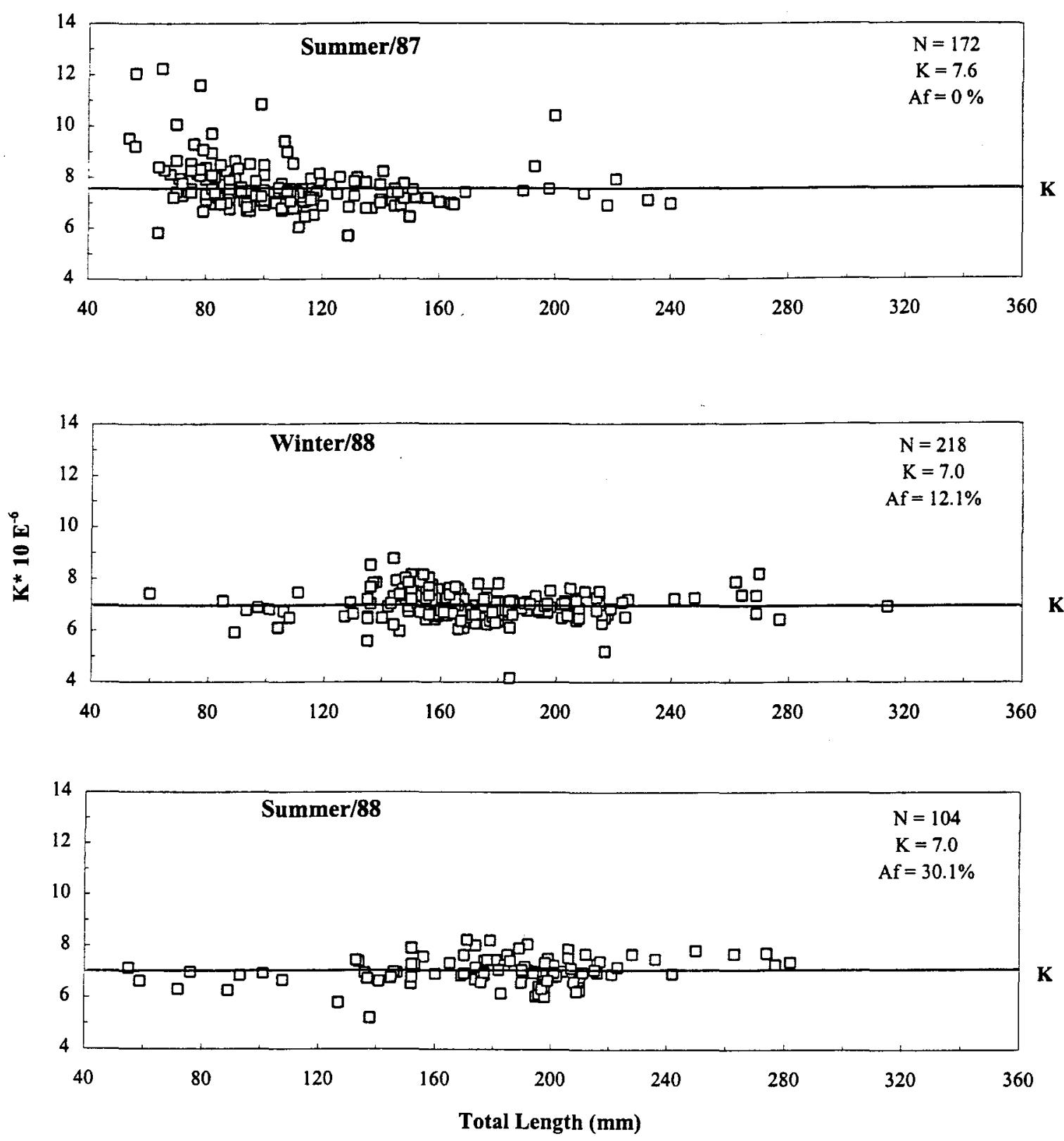

Fig. 6. Condition factors, by length, of the specimens of $P$. punctatus sampled on the Brazilian shelf off Ubatuba during three periods. $\mathrm{N}$ - sample size, $\mathrm{K}$ - condition factor, Af- fraction of mature adults, i.e., fish that are expected to spawn in the current season. 


\section{Discussion}

For an accurate estimate of the food consumption of a population, the estimation of daily food intake for various size classes is essential. In this context, reliable estimates of the evacuation rate, preferably based on field data, are important. Estimates with linear regressions were less accurate, even though they may verify the seasonal tendency as for P. punctatus on the Ubatuba shelf. Nevertheless, even our estimates of the evacuation rate obtained from field data depended on the method used.

The simple exponential evacuation model was applicable for the total and shrimp consumption of $P$. punctatus. Further studies will be required with respect to the digestion of crab prey, because no diel pattern could be found in the stomachs collected at sea. It may thus be advisable to perform laboratory experiments, in spite of the inherent problems in the laboratory-derived gastric evacuation as discussed, e.g., by Allen \& Wootton (1984).

Estimates of daily food intake using the integrated approach are only possible if stomachs are sampled sufficiently often during a 24-hour cycle, i.e., in such a way that the feeding periodicity is adequately covered. This is rather demanding in terms of field work, even if the sampling is distributed over a few days. We believe that the diel patterns we observed in the samples describe the feeding and non-feeding phases adequately, and consequently yield reliable estimates of daily ration.

From the various methods used for estimation of the daily ration, the modified Bajkov model gave 10$15 \%$ lower estimates for the total food consumption of adult fish than Elliott \& Persson'model. The integrated approach yielded estimates $10 \%$ lower than those of the modified Bajkov model. In view of the large variability in the single observation, all results are probably within an acceptable range.

The daily food intake of $P$. punctatus juveniles was about four times higher than that of the adults. This is in accordance with the allometric equation relating food consumption to fish body mass (Webb, 1978), and also with measurements of the specific consumption of oxygen in the routine metabolism of P. punctatus on the Ubatuba shelf (Gomes, pers. comm. ${ }^{\text {) }}$. The hypothesis that annual food consumption of a population per unit biomass $(\mathrm{Q} / \mathrm{B})$ decreases with weight was confirmed by Pauly (1989), and it is also well-known that the highest production in an ecosystem can be obtained from the younger fish (Calow, 1985).

1 Gomes. V. 199 . Instituto Oceanográfico, Universidade de São Paulo. Caixa Postal 66149, 05315-970 São Paulo, Sl', Brasil.
Daily food intake for adult searobin was similar under summer and winter conditions on the Ubatuba shelf. In general, the low water temperatures observed in winter in the temperate zones should be associated with low rates of fish food consumption, and these rates are expected to increase with temperature (Webb, 1978). Worobec (1984) calculated the field estimates of daily ration of winter flounder and showed that the lowest values were registered in the coolest sampling periods and the highest in the warmest periods. Livingston et al. (1986) estimated the daily food intake of six key fish predators in the eastern Bering Sea and verified that most species had the highest values in the summer when the temperature of the water mass is highest. In our study area, the cold bottom water on the shelf off Ubatuba under summer conditions during the sampling periods was only $4^{\circ} \mathrm{C}$ lower than in the winter, but there could be $10^{\circ} \mathrm{C}$ or more of variation (Castro Filho, 1996; Castro Filho et al, 1987), which could decrease the food intake in some measure. However, because the abiotic conditions (high temperature of the upper water layer and luminosity) summer time is also a period of higher primary production (Gaeta et al., 1995) and higher availability of portunid crabs, a major prey of $P$. punctatus (Pires, 1992). These factors could increase the feeding rate, which frequently increases with increased prey density (e.g. Swenson \& Smith, 1976; Pandian \& Vivekanandan, 1985) and associated with the small variation in the water temperature could explain the similar food intake during the two seasons.

Summer is the season of gonadal maturation of P. punctatus (Teixeira \& Haimovici, 1989; Vazzoler, pers. comm. ${ }^{2}$ ), and autumn and winter (warm bottom water) are periods of relatively high growth rate (Braga \& Goitein, 1985). As this species presented the same conditions during summer and winter, it is assumed that the physiologically useful energy available in excess of the routine metabolic requirements is proportionally used for storing as body tissue (i.e., somatic production) or for synthesis of reproductive products (i.e., gonadal production).

Temperature has also generally been shown to have an important effect on food intake of fish belonging to different climatic zones. Pandian \& Vivekanandan (1985) plotted data for 32 temperate and 12 tropical kind of fish and showed that the daily feeding rate of temperate fish ranged from 1.8 to $17.3 \%$ of their body weight (with a mean of $5.9 \%$ ),

2 Vazzoler, A. E. A. de M. 199 . Instituto Oceanográfico, Universidade de São Paulo, Caixa Postal 66149, 05315970 São Paulo, SP, Brasil. 
and that of tropical fish from 4.1 to $36.0 \%$ (with a mean of $17.7 \%$ ). Our data for $P$. punctatus were, consequently, at the lower end of the range for tropical fish, in accordance with the localisation of the study site in a sub tropical area: the south-eastern Brazilian shelf.

With respect to the total population's food consumption, the regression by Palomares \& Pauly (1989), based on the shape of the caudal fin, the size, environmental temperature and food type, yielded by far the lowest estimates. Consequently, with the use of that method the food intake of the population is likely to have been underestimated. This property has been shown to be a general shortcoming of their regression, albeit usually only for intakes above $5 \%$ of body mass per day, i.e., higher than the range in question here. However it should also be kept in mind that this regression was established for fish which move using mainly their caudal fin, as is not strictly true for Triglidae which also "walk" over the ground on their pectoral fins.

The estimate of population food consumption of 17 year $^{-1}$ (or $4.6 \%$ day $^{-1}$ ) based on our daily estimates of food intake appears high if compared with available estimates for demersal fish feeding on invertebrates, as e.g., juvenile gadoids. On the other hand, most of the latter feeding rates have been obtained in temperate regions such as the North Sea with an average bottom temperature $7-8^{\circ} \mathrm{C}$ (e.g., ICES Hydrographic Service, 1933; Dietrich, 1948), roughly $10^{\circ} \mathrm{C}$ lower than the temperature observed off Ubatuba. The regression of Palomares \& Pauly (op. cit.), parameterised for $P$. punctatus, gives a $\mathrm{Q}_{10}$ - factor of 1.64, largely in line with the $Q_{10}$ of 1.7 estimated for total mortality rates of marine fish (which equals total productivity under assumed steady-state conditions) by Regier et al. (1990). De Gee \& Kikkert (1993) provide very rough estimates of daily food intake of the grey gurnard (Eutrigla gurnardus), the dominant triglid in the North Sea, for specimens ranging from 7 to $42 \mathrm{~cm}$. Unfortunately, the growth parameters of this species were unavailable to the present authors. We hence estimated $\mathrm{L}_{\infty}=\mathrm{L}_{\max } / 0.95=44.2 \mathrm{~cm}$ from the observations of De Gee \& Kikkert (1993), and K = 0.079 year $^{-1}$ from the growth performance index $\mathrm{F}^{*}=$ $\log _{10} K+2 . \log _{10} L_{\infty}=2.186$ obtained from the same species in the Mediterranean Sea (Erzini, 1991). Assuming the same total mortality rate as for $P$. punctatus, a population-based estimate of food consumption of 13.9 year $^{-1}$ (Table 4) was obtained, which exceeds even our estimate if the temperature effect $\left(Q_{10}\right)$ is taken into account. We consequently trust that, through high at first glance, our estimates are realistic.

\section{Acknowledgements}

We wish to thank the Interministerial Commission of Brazilian Sea Resources (CIRM) who made this project possible by financial support for the integrated project "Utilização Racional dos Ecossistemas Costeiros da Região Tropical Brasileira - Estado de São Paulo". We could also thank the Brazilian Research Council CNPq (Science and Technology Ministry of Brazil), for supporting the international scientific exchange. Finally, our thanks are due to Stepan Neuenfeldt and Marcia R. Gasparro for their assistance in preparing some of the graphs, as well as to two anonimous referees.

\section{References}

Allen, J. R. M. \& Wootton, R. J. 1984. Temporal patterns in diet and rate of food consumption of the three-spined stickleback (Gasterosteus aculeatus L.) in Lyn Frongoch, an upland Welsh lake. Freshwat. Biol., 14(4):335-346.

Bajkov, A. D. 1935. How to estimate the daily food consumption of fish under natural conditions. Trans. Am. Fish. Soc., 65:288-289.

Braga, F. M. de S. \& Goitein, R. 1985. Estudo morfológico da sagitta da cabrinha (Prionotus punctatus, Triglidae), da região da Ilha Anchieta (Lat. $23^{\circ} 33^{\prime} \mathrm{S}$ - Long. $45^{\circ} 05^{\prime} \mathrm{W}$ ), Ubatuba, litoral norte do Estado de São Paulo, Brasil. Naturalia, 10:65-74.

Calow, P. 1985. Adaptive aspects of energy allocation. In: Tytler, P. \& Calow, P. eds Fish energetics: new perspectives. London, Croom Helm. p. 13-31.

Castro Filho, B. M. 1996. Correntes e massas de água da plataforma continental norte de São Paulo. Tese de Livre-Docência. Universidade de São Paulo, Instituto Oceanográfico. 248p.

Castro Filho, B. M. de; Miranda, L. B. de \& Miyao, S. Y. 1987. Condições hidrográficas na plataforma continental ao largo de Ubatuba: variações sazonais e em média escala. Bolm Inst. oceanogr., S Paulo, 35(2): 135-151.

De Gee, A. \& Kikkert, A. H. 1993. Analysis of the Grey Gurnard (Eutrigla gurnardus) samples collected during the 1991 International Stomach Sampling Project. ICES C. M. 1993/G:14. 25p. 
Dietrich, G. 1948. Der Jehrliche gang der temperaturen und salzgehalts-schichtung in den britischen randmeeren und in der nord-und ostee: Atlas. Hamburg, Deutsches Hydrographisches Institut.

Durbin E. G.; Durbin, A. G.; Langton, R. W. \& Bowman, R. E. 1983. Stomach contents of silver hake, Merluccius bilinearis and Atlantic cod, Gadus morhua, and estimation of their daily ration. Fish. Bull. U.S., 81(3):437454.

Eggers, D. M. 1979. Comments on some recent methods for estimating food consumption by fish. J. Fish. Res. Bd Can., 34:290-294.

Elliott, J. M. \& Persson, L. 1978. The estimation of daily rates of food consumption for fish. J. Anim. Ecol., 47:977-991.

Erzini, K. 1991. A compilation of data on variability in length-age in marine fishes. Working paper 77. Fish Stock Assessment, Tile XII, Collaborative Research Support Program. University of Rhode Island. (unpaged).

Figueiredo, J. L. \& Menezes, N. A. 1980. Manual de peixes marinhos do sudeste do Brasil. III.Teleostei (2). São Paulo, Museu de Zoologia da Universidade de São Paulo. 90p.

Furtado, C. \& Mahiques, M. M. 1990. Distribuiçã̀o de sedimentos em regiões costeiras e plataforma continental norte do Estado de São Paulo. In: SIMPÓSIO DE ECOSSISTEMAS DA COSTA SUL E SUDESTE BRASILEIRA: ESTRUTURA, FUNÇÃO E MANEJO. 2. Anais. Águas de Lindóia, 1990. São Paulo, ACIESP, (71):20-29.

Gaeta, S. A.; Abe, D. S.; Metzler, P. M. \& Teixeira, C. 1995. Photosynthetic parameters of the coastal marine phytoplankton from the Ubatuba region, Brazil. Publção. esp. Inst. oceanogr., S Paulo, (11):163-169.

Gulland, J. A. 1983. Fish stock assessment: a manual of basic methods. New York, John Willey. 223p.

Héroux, D. \& Magnan, P. 1996. In situ determination of food ration in fish: review and field evaluation. Environ. Biol. Fishes, 46:6174.
ICES Hydrographic Service. 1933. Atlas de témperature et salinité de l'eau de surface de la Mer du Nord e de la Manche. Copenhagen, ICES. 32p.

Jarre-Teichmann, A. 1992. MAXIMS - A computer program for estimating the food consumption of fish. ICES C.M. 1992/G:62. 12p.

Jarre, A.; Palomares, M. L.; Soriano, M., Sambilay Jr., V. C. \& Pauly, D. 1991. Some new analytical and comparative methods for estimating the food consumption of fishes. ICES Mar. Sci. Symp., 193:99-108.

Jarre-Teichmann, A.; Palomares, M. L.; Soriano, M., Gayanilo Jr., F. C. \& Pauly, D. 1992. A user's manual for MAXIMS (Version 1.0): A computer program for estimating the food consumption of fishes from diel stomach contents data and population parameters. ICLARM Software 4. Manila, International Center for Living Aquatic Resources Management. 28p.

Livingston, P. A.; Dwyer, D. A.; Wencker, D. L.; Yang, M. S. \& Lang, G. M. 1986. Trophic interactions of key fish species in the eastern Bering Sea. Bull. int. N. Pacif. Fish. Commn, 47(2):49-65.

Palomares, M. L. D. \& Pauly, D. 1989. A multiple regression model for predicting the food consumption of marine fish populations. Aust. J. mar. Freshwat. Res., 40:259-273.

Pandian, T. J. \& Vivekanandan, E. 1985. Energetics of feeding and digestion. In: Tytler, P. \& Calow, P. eds Fish energetics: new perspectives. London, Croom Helm. p. 99-124.

Pauly, D. 1986. A simple method for estimating the food consumption of fish populations from growth data and food conversion experiments. Fish. Bull. U.S., 84(4):827-840.

Pauly, D. 1989. Food consumption by tropical and temperate fish populations: some generalizations. J. Fish Biol., 35(A):11-20.

Peria, C. G. 1995. Estimativa da taxa de produção e da relação produção/biomassa média $(\mathrm{P} / \mathrm{B})$, de peixes demersais do ecossistema costeiro de Ubatuba, SP, Brasil. Dissertação de mestrado. Universidade de São Paulo, Instituto Oceanográfico. $141 \mathrm{p}$. 
Pires, A. M. S. 1992. Structure and dynamics of benthic megafauna on the continental shelf offshore of Ubatuba, Southeastern Brazil. Mar. Ecol. Prog. Ser., 86(I):63-76.

Regier, H. A.; Holmes, J. A. \& Pauly, D. 1990. Influence of temperature changes on aquatic ecosystems: an interpretation of empirical data. Trans. Am. Fish. Soc., 199(2):374-389.

Ricker, W. E. 1975. Computation and interpretation of biological statistic of fish populations. Bull. Fish. Res. Bd Can., (191):382p.

Rocha, G. R. A. 1990. Distribuição, abundância e diversidade da ictiofauna na região de UbatubaSP $\left(23^{\circ} 20^{\prime}-24^{\circ} 00^{\prime} \mathrm{S} ; 44^{\circ} 30^{\prime}-45^{\circ} 30^{\prime} \mathrm{W}\right)$, Brasil. Dissertação de mestrado. Universidade de São Paulo, Instituto Oceanográfico. $2 \mathrm{v}$.

Soares, L. S. H. \& Apelbaum, R. 1994. Atividade alimentar diária da cabrinha Prionotus punctatus (Teleostei: Triglidae) do litoral de Ubatuba, Brasil. Bolm Inst. oceanogr., S Paulo, 42(1/2):85-98.

Swenson, W. A. \& Smith Jr., L. L. 1973. Gastric digestion, food consumption, feeding periodicity and food conversion efficiency in walleye (Stizostedion vitreum vitreum). J. Fish. Res. Bd Can., 30(9): 1327-1336.
Teixeira, A. R. L. \& Haimovici, M. 1989. Distribuição, reprodução e hábitos alimentares de Prionotus punctatus e $P$. nudigula (Pisces:Triglidae) no litoral do Rio Grande do Sul, Brasil. Atlântica, Rio Grande, 11(1):13-45.

Webb, W. 1978. Partitioning of energy into metabolism and growth. In: Gerking, S. D., ed. Ecology of freshwater fish production. New York, John Willey. p. 184-213.

Worobec, M. N. 1984. Field estimates of daily ration of winter flounder, Pseudopleuronectes americanus (Walbaum), in a southern New England salt pond. J. expl mar. Biol. Ecol., 77(1):183-196.

Zar, J. H. 1996. Biostatistical analysis. New Jersey, Prentice Hall. 662p.

(Manuscript received 15 September 1997; revisid 12 February 1998; accepted 15 April 1998) 